\title{
Phosphorus solubility in aerosol particles related to particle sources and atmospheric acidification in Asian continental outflow
}

\author{
Jinhui Shi ${ }^{1,2}$, Nan Wang ${ }^{1}$, Huiwang Gao ${ }^{1,2}$, Alex R. Baker ${ }^{3}$, Xiaohong Yao ${ }^{1,2}$, and Daizhou Zhang ${ }^{4}$ \\ ${ }^{1}$ Key Laboratory of Marine Environmental Science and Ecology, Ocean University of China, \\ Ministry of Education of China, Qingdao 266010, China \\ ${ }^{2}$ Laboratory for Marine Ecology and Environmental Science, Qingdao National Laboratory for Marine Science \\ and Technology, Qingdao 266237, China \\ ${ }^{3}$ Centre for Ocean and Atmospheric Sciences, School of Environmental Sciences, University of East Anglia, \\ Norwich, NR4 7TJ, UK \\ ${ }^{4}$ Faculty of Environmental and Symbiotic Sciences, Prefectural Kumamoto University, \\ Kumamoto 862-8502, Japan
}

Correspondence: Jinhui Shi (engroup@ouc.edu.cn)

Received: 29 August 2018 - Discussion started: 9 October 2018

Revised: 31 December 2018 - Accepted: 10 January 2019 - Published: 22 January 2019

\begin{abstract}
The continent-to-ocean supply of phosphorus (P) in the soluble state, recognized as bioavailable $\mathrm{P}$, via the atmosphere is hypothesized to be crucial to the biological cycle in offshore surface seawater. To investigate the solubility of $\mathrm{P}$ in aerosol particles moving towards the northwestern Pacific from the Asian continent, we measured the total $\mathrm{P}$ (TP), total dissolved P (TDP) and dissolved inorganic P (DIP) in aerosols at Qingdao $\left(36^{\circ} 06^{\prime} \mathrm{N}, 120^{\circ} 33^{\prime} \mathrm{E}\right)$, a coastal city in eastern China. The samples were collected in December 2012 and January 2013 (winter) and in March and April 2013 (spring), when the middle-latitude westerly wind was prevailing. On average, $\mathrm{P}$ solubility, i.e., the ratio of TDP to $\mathrm{TP}$, was $32.9 \pm 16.7 \%$ in winter and $21.3 \pm 9.8 \%$ in spring, and the TP concentrations in the two seasons were similar. This seasonal solubility difference is attributed to the aerosol sources containing the P. Particles in winter were predominantly anthropogenic particles from local and regional areas, and particles in spring were significantly influenced by natural dust from the arid and semiarid areas in the inland part of the continent. Moreover, acidification processes associated with the formation of sulfate and nitrate in the winter samples enhanced $\mathrm{P}$ solubility, suggesting that the $\mathrm{P}$ in anthropogenic particles was more susceptible to the production of acidic species than that in natural dust particles. There was a strong positive correlation between $\mathrm{P}$ solubility and relative humidity (RH). P solubility was usually less than $30 \%$ when
\end{abstract}

RH was below $60 \%$, even when the content of acidic species and/or anthropogenic particles in the aerosols was high, suggesting humidity had a critical role in the production of TDP. In addition, the proportion of DIP in TDP was high when the particles were predominantly anthropogenic, and the proportion of dissolved organic P (DOP; quantified as TDP minus DIP) in TDP was high when the particles were dominated by natural dust. These results indicate that, as the contents of bioavailable $\mathrm{P}$ in Asian continent outflows are closely dependent on the aerosol particle origins, atmospheric acidic processes could convert $\mathrm{P}$ into a bioavailable state under certain meteorological conditions. Therefore, the recent severe air pollution over East Asia might have enhanced the input of bioavailable $\mathrm{P}$ to downwind marine areas.

\section{Introduction}

Phosphorus (P) is one of the limiting nutrients for primary production in marine ecosystems, affecting marine phytoplankton growth, community structure composition and nitrogen fixation (Elser et al., 2007; Paytan and McLaughlin, 2007; Peñuelas et al., 2013). Atmospheric P deposition likely has an important contribution to phosphate and induces the growth of phytoplankton in surface seawater outside estuary areas, especially in offshore areas and regions where $\mathrm{P}$ 
limits phytoplankton growth (Karl and Tien, 1997; Paytan and McLaughlin, 2007; Mackey et al., 2012a). Recent studies have found that the atmospheric input of anthropogenic $\mathrm{N}$ to the North Pacific and its marginal sea is increasing (Kim et al., 2013, 2014), while the P concentration in the surface seawater has been declining for nearly 40 years (Kodama et al., 2016), indicating that the nutrient structure of marine ecosystems is changing to $\mathrm{P}$ limitation.

Atmospheric $\mathrm{P}$ is derived from natural and anthropogenic sources, including mineral dust, sea salt, primary biogenic sources, volcanic eruptions, biomass burning, fossil fuel combustion and agricultural fertilizers (Mahowald et al., 2008; Anderson et al., 2010; Tipping et al., 2014; Weinberger et al., 2016). It has been widely recognized that mineral dust is the main source of atmospheric P. Based on a combination of model simulations and field observations, Mahowald et al. (2008) reported that mineral aerosols contributed to approximately $82 \%$ of atmospheric $\mathrm{P}$ at a global scale, while anthropogenic $\mathrm{P}$ contributed to approximately $5 \%$ of atmospheric P globally. Recent studies have highlighted the contributions of anthropogenic sources. Weinberger et al. (2016) suggested that coal combustion is a substantial source of atmospheric $\mathrm{P}$ and that the relative content of $\mathrm{P}$ in coal fly ashes could be as high as $3500 \mu \mathrm{g} \mathrm{g}^{-1}$. Srinivas and Sarin (2015) studied the sources of $\mathrm{P}$ in the atmospheric aerosols of Bengal Bay in the northern Indian Ocean and found that $75 \%$ of aerosol $\mathrm{P}$ was from agricultural fertilizers and biomass burning. A recent estimation by Wang et al. (2015) showed that combustion-related emissions could contribute more than $50 \%$ of the global atmospheric P. These results suggest that anthropogenic emissions of $\mathrm{P}$ have likely increased considerably in recent years and that the states of $\mathrm{P}$ in atmospheric aerosols need to be carefully quantified.

P solubility, i.e., the ratio of total dissolved P (TDP) to total $\mathrm{P}$ (TP), is usually used to characterize the bioavailability of atmospheric P (Anderson et al., 2010) because the soluble fraction of $\mathrm{P}$ in aerosols is believed to be the form that can be directly assimilated by marine phytoplankton (Mackey et al., 2012b). Unfortunately, observational data on the solubility of atmospheric $\mathrm{P}$ are very limited, and the available data show a wide range of $\mathrm{P}$ solubility, ranging from $2 \%$ to $100 \%$ in different sea areas (e.g., Baker et al., 2006a, b; Mahowald et al., 2008).

Dissolved $\mathrm{P}$ in aerosols includes dissolved inorganic $\mathrm{P}$ (DIP) and dissolved organic P (DOP). Only DIP has been frequently analyzed by previous studies of $\mathrm{P}$ solubility in aerosols (Srinivas and Sarin, 2015) because DIP is considered directly available to marine phytoplankton and the predominant component of TDP (Mahowald et al., 2008). However, some studies have found that DOP can be converted to bioavailable P by enzymatic reactions (Mackey et al., 2012a) and accounts for $20 \%-83 \%$ of TDP in global atmospheric depositions (Kanakidou et al., 2012), although the contribution of DOP to TDP is sometimes very low (Izquierdo et al., 2012; Myriokefalitakis et al., 2016).
P solubility in aerosols from different sources varies greatly and is generally low in particles from mineral sources and high in particles from anthropogenic sources. In the Mediterranean atmosphere, $\mathrm{P}$ solubility ranges from $2 \%$ to $20 \%$ with an average of $10 \%$ in aerosols affected by Saharan dust, whereas $\mathrm{P}$ solubility ranges from $30 \%$ to $79 \%$ with an average of $50 \%$ in aerosols with anthropogenic sources (Herut et al., 2002). Similar results were also observed in the Atlantic atmosphere, where the $\mathrm{P}$ solubility in aerosols affected by Saharan dust is approximately $8 \%$ and can be up to $87 \%$ in aerosols originating from terrestrial air masses in South America (Baker et al., 2006a, b). In the South China Sea, $\mathrm{P}$ solubility in aerosols related to biomass combustion is around $50 \pm 14 \%$ (Hsu et al., 2014). These results imply that an increase in the relative amounts of aerosols from anthropogenic sources might lead to the increase in bioavailable P. In addition, atmospheric acidic processes associated with anthropogenic pollutants may transform unreactive $\mathrm{P}$ to bioavailable P. Recent model studies predict that the acid dissolution process increases the fraction of bioavailable $\mathrm{P}$ from $\sim 10 \%$ globally at labile pools to $42 \%$ in the Pacific Ocean, with the mean value of $22 \%$ in the global marine atmosphere (Herbert et al., 2018). Myriokefalitakis et al. (2016) estimated that acid-driven solubilization flux of $\mathrm{P}$ from mineral dust contributed about one-third to the global TDP atmospheric source.

The Yellow Sea is a marginal sea of the Pacific Ocean that is frequently affected by both Asian dust from arid and semiarid areas in inland regions of the Asian continent and anthropogenic pollutants from urban agglomerations in northern China (e.g., Zhang and Gao, 2007; Zhang et al., 2018; Shi, et al., 2012; Wang et al., 2013). For example, a dust storm that occurred in May 2017 moved across the North Pacific within a week and deposited $5.3 \mathrm{Tg}$ of aeolian dust across the North Pacific Ocean (Zhang et al., 2018). In recent years, anthropogenic emissions have rapidly increased with the acceleration of industrialization and urbanization over northern China. Prevailing westerly winds in the Northern Hemisphere middle latitudes can carry anthropogenic aerosols traveling over the North Pacific (Lyu et al., 2017; Joos et al., 2017). Over the last 30 years, the structure of nutrients in the Yellow Sea water has exhibited an alternation from $\mathrm{N}$ limitation to potential $\mathrm{P}$ limitation (Wei et al., 2015). However, there are no data on $P$ solubility in the atmospheric aerosols outflowing from the Asian continent towards the Yellow Sea and the northern Pacific, which hinders further understanding of the influence of $\mathrm{P}$ deposition on the biological cycles in the surface seawater of those ocean areas.

In this study, we investigated TP and TDP, including DIP and DOP, in aerosols collected at Qingdao. The city of Qingdao is located in the coastal area of the Yellow Sea. In winter and spring, when westerly winds prevail, aerosol particles originating from the Asian continent, including natural dust and anthropogenic particles, are frequently blown from the continent and enter the marine air over the Yellow Sea and 
subsequently over the northern Pacific (Zhang et al., 2005, 2018; Joos et al., 2017; Qi et al., 2018). The objectives of this paper are to characterize (1) the concentrations of TP, TDP, DIP and DOP in aerosols in the coastal areas of the Yellow Sea, (2) the relative contribution of DOP and DIP to TDP, (3) P solubility in aerosols in the Asian continental outflow, and (4) the influences of dust loads, particle sources, atmospheric acidification and ambient relative humidity (RH) on P solubility.

\section{Methods}

\subsection{Sample collection}

Aerosol samples of total suspended particulates (TSP) were collected between 1 December 2012 and 31 January 2013 (winter) and between 1 March and 30 April 2013 (spring). The aerosol sampler used for collection was a high-volume TSP sampler (KC-1000, Laoshan Electron Ltd., Qindao, China) set up on the roof of a building at the Ocean University of China in Qingdao $\left(36^{\circ} 06^{\prime} \mathrm{N}, 120^{\circ} 33^{\prime} \mathrm{E}\right)$. The roof was approximately $65 \mathrm{~m}$ above sea level, and the building was $<1000 \mathrm{~m}$ from the coast of the Yellow Sea. In total, 112 samples were collected, of which 60 were collected in the winter period and 52 were collected in the spring period. Each aerosol sample was collected onto an acid-washed fiber filter (Whatman-41, $20.3 \mathrm{~cm} \times 25.4 \mathrm{~cm}$ ) at a flow rate of $1.05 \mathrm{~m}^{3} \mathrm{~min}^{-1}$ for $24 \mathrm{~h}$, and the total sampling air was approximately $1500 \mathrm{~m}^{3}$. Operational filter blanks were also collected. All samples were sealed in polyethylene bags and stored in a freezer at $-20^{\circ} \mathrm{C}$ until subsequent analyses.

During the sampling periods, the particle concentrations in six size ranges were measured using a laser optical particle counter (OPC, ARTI model HHPC-6). The OPC had six channels (i.e., 0.3, 0.5, 0.7, 1.0, 2.0 and $5.0 \mu \mathrm{m}$ ) and was run at a flow rate of $2.83 \mathrm{~L} \mathrm{~min}^{-1}$ with a $15 \mathrm{~min}$ time resolution. Meteorological conditions, including temperature, $\mathrm{RH}$, wind speed and direction, and visibility were obtained from the MICAPS meteorology data provided by the China Meteorological Administration. The $24 \mathrm{~h}$ average values of these variables during the sampling periods are illustrated in Fig. S1 in the Supplement.

\subsection{Sample analysis}

The sample filters and blank filters were subdivided into portions using an acid-cleaned ceramic knife under a class-100 laminar flow hood. For the analysis of TP, a piece of the filter was digested with $4 \mathrm{~mL}$ of $70 \% \mathrm{HNO}_{3}$ and $1 \mathrm{~mL}$ of $49 \%$ HF (all ultra-pure grades) in a high-pressure Teflon jar at $180^{\circ} \mathrm{C}$ for $48 \mathrm{~h}$. Then, the digested sample solution was heated on an electrothermal board at $160^{\circ} \mathrm{C}$ until the acid fumes dissipated. After being cooled to room temperature, the residue was redissolved, transferred to a colorimetric tube and made up to a volume of $25 \mathrm{~mL}$ for determina- tion of TP. For the analysis of soluble P, another piece of the sample filter was ultrasonically extracted with $15 \mathrm{~mL}$ MilliQ water $(\geq 18.2 \mathrm{M} \Omega \mathrm{cm})$ for $20 \mathrm{~min}$ at $0{ }^{\circ} \mathrm{C}$. The extract was then filtered through a microporous membrane (pore size of $0.45 \mu \mathrm{m}$ ). The extraction was repeated once, and then the filter was rinsed three times with Milli-Q water. All the extractive solutions were combined and finally made up to a volume of $50 \mathrm{~mL}$. The filtered extract was divided into two equal parts: one directly for the determination of DIP and the other autoclaved with $2.5 \mathrm{~mL}$ alkaline potassium persulfate solution $\left(0.375 \mathrm{~mol} \mathrm{~L}^{-1} \mathrm{NaOH}, 0.185 \mathrm{~mol} \mathrm{~L}^{-1} \mathrm{~K}_{2} \mathrm{~S}_{2} \mathrm{O}_{8}\right.$ and $0.484 \mathrm{~mol} \mathrm{~L}^{-1} \mathrm{H}_{3} \mathrm{BO}_{3}$ mixed solution) at $120^{\circ} \mathrm{C}$ for $30 \mathrm{~min}$ for the determination of TDP. DOP was obtained by the difference between TDP and DIP.

Phosphorus in the prepared sample solutions was measured by the molybdenum blue technique with colorimetric detection. A color reagent comprising a mixture of sulfuric acid, ammonium molybdate, ascorbic acid and antimony potassium tartrate was added into the solutions, and $\mathrm{P}$ in the solutions was quantified using a UV spectrophotometer (T-6 new century, Beijing general analysis) with a $5 \mathrm{~cm}$ quartz cell at $880 \mathrm{~nm}$ once the color was developed. The detection limit was $0.07 \mu \mathrm{mol} \mathrm{L}^{-1}$ (approximately $0.6 \mathrm{ng} \mathrm{m}^{-3}$ ), defined as 3 times the standard deviation of the blanks. The values for the blanks (i.e., blank filters and reagents) were below the detection limit. The relative standard deviations of replicate analysis of the sample extracts were within $3 \%$. The accuracy of the TP analysis procedure used in this study was checked using a soil sample standard reference material as a substitute (GBW07408, provided by the Geophysical and Geochemical Survey Institute, China). GBW07408 was included in all analytical runs with the same treatment as sample filters, and the $\mathrm{P}$ recoveries were $95 \%-105 \%$ with an average of $98 \%$ $(n=10)$.

Total and soluble trace elements, including $\mathrm{Al}, \mathrm{Fe}, \mathrm{Mn}, \mathrm{Ba}$, $\mathrm{Ca}, \mathrm{Zn}, \mathrm{Ni}, \mathrm{As}, \mathrm{Cd}, \mathrm{Pb}$ and $\mathrm{K}$, in samples were analyzed using an Agilent 7500c octopole-based inductively coupled plasma mass spectrometer (ICP-MS). Water-soluble inorganic ions, including $\mathrm{Na}^{+}, \mathrm{K}^{+}, \mathrm{Mg}^{2+}, \mathrm{NH}_{4}^{+}, \mathrm{Ca}^{2+}, \mathrm{Cl}^{-}, \mathrm{NO}_{2}^{-}, \mathrm{NO}_{3}^{-}$ and $\mathrm{SO}_{4}^{2-}$, were analyzed using a Dionex ICS-3000 ion chromatograph. The full details of the sample extraction and analytical procedures for aerosol trace element and ion analyses are described in Shi et al. $(2012,2013)$.

\subsection{Aerosol-specific surface area calculation}

The specific surface areas of aerosol particles were calculated to investigate the possible dependence of P solubility on chemical conversions occurring in the aerosol surface layer. The specific surface area of an aerosol sample was defined as the ratio of the surface area of the particles to the particle mass loading. The aerosol surface area was estimated from the size-segregated number concentrations of aerosol particles measured by the OPC in the sample collection period. We made a simplistic assumption of spherical particles, and 
hence

$S_{i}=\sum_{j=1}^{n}\left[C_{i, j} \cdot 4 \pi \cdot\left(\frac{d_{j}}{2}\right)^{2}\right]$,

where $S_{i}$ is the total surface area of the particles in the $i$ th aerosol sample, $C_{i, j}$ is the average number concentration of the corresponding aerosol sample in the $j$ th size range, and $d_{j}$ is the diameter of the particulates in the $j$ th size range. Although the smallest detectable diameter of the particle counter was $0.3 \mu \mathrm{m}$, we consider the estimated specific areas to represent the areas associated with $\mathrm{P}$ in the samples because more than $90 \%$ of TP is in the $>0.32 \mu \mathrm{m}$ particles (Vicars et al., 2010). The particle mass loading was estimated from $\mathrm{Al}$ contents by assuming that all aerosol $\mathrm{Al}$ was derived from mineral dust, in which $\mathrm{Al}$ comprises $8 \%$ of the mineral aerosol mass (Taylor, 1964).

\section{Results and discussion}

\subsection{P concentration}

The concentration of TP ranged from 24.7 to $392.6 \mathrm{ng} \mathrm{m}^{-3}$, and the mean TP concentration was $125.5 \pm 59.8 \mathrm{ng} \mathrm{m}^{-3}$ (Fig. 1, Table 1). The highest and second highest values were observed in the samples on 9 March and 8 April when dusty weather occurred and the concentration of both total Fe and total $\mathrm{Al}$, the representative elements of mineral dust, exceeded $10000 \mathrm{ng} \mathrm{m}^{-3}$. The TDP concentration ranged from 5.1 to $114.6 \mathrm{ng} \mathrm{m}^{-3}$, and the mean TDP concentration was $32.4 \pm 23.2 \mathrm{ng} \mathrm{m}^{-3}$. Unlike TP, the highest concentration of TDP did not appear in the two dust samples and was instead measured in the samples collected during the haze and foggy days, mostly in January.

The DIP concentration in the TDP ranged from 1.5 to $102.6 \mathrm{ng} \mathrm{m}^{-3}$, with an average concentration of $21.8 \mathrm{ng} \mathrm{m}^{-3}$, accounting for $8.5 \%-98.7 \%$ of the TDP (Fig. 2). The DOP concentration in the TDP ranged from below the detection limit to $41.0 \mathrm{ng} \mathrm{m}^{-3}$, with an average concentration of $10.7 \mathrm{ng} \mathrm{m}^{-3}$, accounting for $1.3 \%-91.5 \%$ of the TDP. DIP and DOP accounted, on average, for approximately $60 \%$ and $40 \%$ of the TDP, respectively, indicating an appreciable contribution of DOP to the TDP.

Table 1 also shows the results of previous studies on coastal and marine aerosol $\mathrm{P}$ concentrations. The TP concentration we observed in this study was lower than that observed in Singapore in spring (He et al., 2011) but slightly higher than the values obtained at Huaniao Island in the East China Sea (Guo et al., 2014) and higher than those observed at coastal sites of Spain and the USA (Izquierdo et al., 2012; Zamora et al., 2013). The TP concentration at Qingdao was approximately 1 order of magnitude higher than that in the marine atmosphere (Baker et al., 2006b; Hsu et al., 2014; Sun et al., 2015). The DIP concentration in this study was obviously higher than those in the South China Sea, the Gulf of Aqaba and Miami, USA (Hsu et al., 2014; Chen et al., 2007; Zamora et al., 2013), but was lower than the values reported in Singapore and the Indian Ocean (He et al., 2011; Srinivas and Sarin, 2012). In fact, DOP was not measured in those studies (Table 1). Chen et al. (2007) studied DOP in aerosols over the Gulf of Aqaba and reported a DOP concentration and contribution of DOP to TDP that were similar to the results of this study.

There was a difference in the concentrations of total and dissolved $\mathrm{P}$ between the winter and spring (Figs. 1, 2). The average TP concentration in the spring was $128.6 \pm$ $73.2 \mathrm{ng} \mathrm{m}^{-3}$, slightly higher than that in the winter, i.e., $122.9 \pm 45.6 \mathrm{ng} \mathrm{m}^{-3}$. However, there was no statistically significant difference between the TP values of the two seasons $(p>0.05)$. Guo et al. (2014) also found that the atmospheric TP concentration in spring was higher than that in other seasons at Huaniao Island in the East China Sea. In contrast, over the Gulf of Aqaba, a higher aerosol TP concentration occurred in winter than in other seasons, although there were no statistically significant seasonal variations in TP (Anderson et al., 2010).

In contrast to the small seasonal difference in TP, TDP was higher in winter, with an average concentration of $40.5 \pm$ $27.7 \mathrm{ng} \mathrm{m}^{-3}$, and lower in spring, with an average concentration of $23.0 \pm 11.0 \mathrm{ng} \mathrm{m}^{-3}$. In TDP, the DIP in winter averaged $31.9 \pm 23.4 \mathrm{ng} \mathrm{m}^{-3}$, significantly higher than that in spring, which had an average of $10.0 \pm 10.2 \mathrm{ng} \mathrm{m}^{-3}$; in contrast, DOP in spring, with an average concentration of $13.0 \pm 7.5 \mathrm{ng} \mathrm{m}^{-3}$, was higher than that in winter, with an average concentration of $8.6 \pm 7.4 \mathrm{ng} \mathrm{m}^{-3}$. Furthermore, the ratio of DOP to TDP in spring was approximately $61 \%$, which was significantly higher than that in winter, i.e., $23 \%$. This result was probably caused by the release of primary biological particles and agriculture activities in spring (Mahowald et al., 2008; Kanakidou et al., 2012; Paytan and McLaughlin, 2007). Chen et al. (2006) also reported that, among all seasons, aerosols in spring had the largest percentage of organic P loads, a result potentially associated with terrestrial and marine biological activity.

TP was closely correlated with $\mathrm{Al}, \mathrm{Fe}, \mathrm{Ca}, \mathrm{Mn}$ and Ba (Table S1 in the Supplement). This is consistent with the fact that mineral particles from surface soils are the main origin of $\mathrm{P}$. TP was also correlated with heavy metals of $\mathrm{Cd}, \mathrm{As}, \mathrm{Ni}, \mathrm{Zn}$ and $\mathrm{Pb}$ and with $\mathrm{K}$. These results again support that the TP was derived from natural mineral dust, anthropogenic particles, biogenic particles and emissions from biomass burning. Moreover, the correlation coefficients between TP and crustal elements ( $\mathrm{Al}, \mathrm{Fe}, \mathrm{Ca}, \mathrm{Mn}$ and $\mathrm{Ba}$ ) were larger in spring than in winter, while the close correlation between the TP and anthropogenic elements was observed in winter. This result suggests that a large proportion of TP in the winter was from anthropogenic sources. In contrast, the TP in the spring aerosols was substantially from crustal origins.

The DIP fraction in the TP also showed a significant correlation with $\mathrm{Cd}$, $\mathrm{As}, \mathrm{Ni}, \mathrm{Zn}, \mathrm{Pb}, \mathrm{K}$, non-sea salt (nss)- $\mathrm{SO}_{4}^{2-}$ 


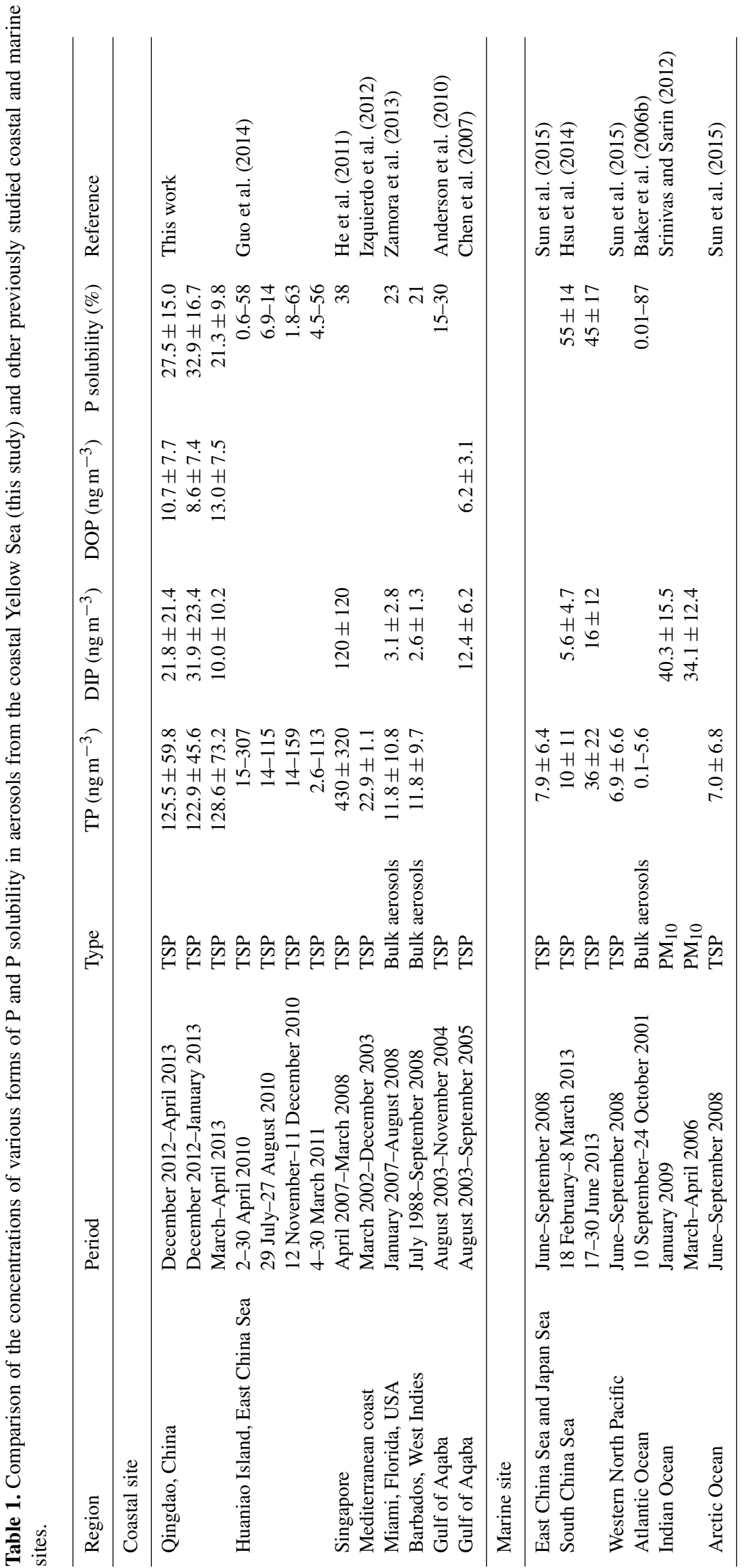



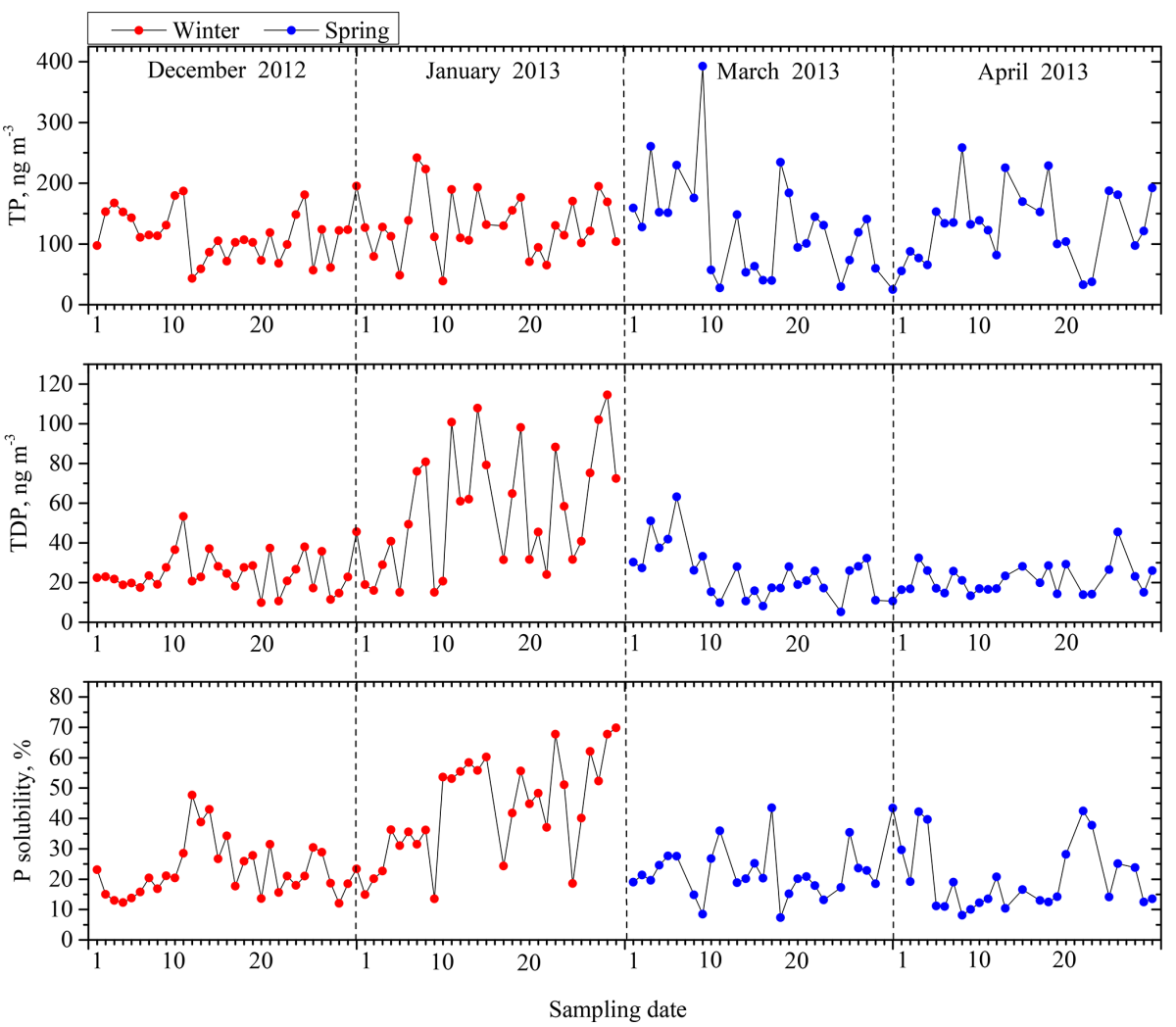

Figure 1. Time series of total and dissolved $\mathrm{P}$ concentrations (TP and TDP) and P solubility.

and $\mathrm{nss}-\mathrm{K}^{+}$but had a minuscule correlation with $\mathrm{Al}, \mathrm{Fe}$, $\mathrm{Ca}$ and $\mathrm{Ba}$ (Table $\mathrm{S} 1$ ). This suggests that the DIP mainly originated from anthropogenic sources (particularly fossil fuel combustion and biomass burning) and biogenic sources (Weinberger et al., 2016; Zamora et al., 2013). Aerosol DOP is considered to be mainly derived from primary biological particles and biomass burning (Chen et al., 2006), which is supported by the correlation between DOP and $\mathrm{K}$ and nss- $\mathrm{K}^{+}$ in the samples. We found that the DOP had a significant correlation with crustal source indicators $(\mathrm{Al}, \mathrm{Fe}, \mathrm{Mn}, \mathrm{Ba})$ and anthropogenic source indicators ( $\mathrm{Cd}, \mathrm{As}, \mathrm{Zn}, \mathrm{Pb})$. Therefore, soil dust and anthropogenic emissions are potential sources of atmospheric DOP. Myriokefalitakis et al. (2016) reported that, on the global scale, approximately $50 \%$ of secondary DOP was attributed to the ageing of biological P primarily contained in aerosols, and the contributions of soil dust, anthropogenic combustion and biomass burning ageing to secondary DOP were approximately $25 \%, 15.6 \%$ and $9.4 \%$, respectively. In addition, bioaerosols were enriched in longrange-transported dust plumes in Beijing and the northwestern Pacific for Asian dust and in the Mediterranean and the Atlantic for African dust (Yuan et al., 2017; Hara and Zhang, 2012; Griffin et al., 2007; Kanakidou et al., 2018). Therefore, the observed correlation between DOP and crustal elements could be the consequence of the presence of bioaerosols in dust plumes.

\subsection{P solubility}

P solubility ranged from $7.3 \%$ to $69.8 \%$ (Fig. 1). Two low solubility values occurred in the dust samples due to the high concentration of TP and low concentration of TDP. High values occurred in the haze and foggy day samples, mostly in January. The average P solubility was $27.5 \%$, which is in agreement with the values reported at various coastal sites (Table 1). Anderson et al. (2010) reported that $15 \%-30 \%$ of $\mathrm{P}$ in Gulf of Aqaba aerosols was soluble. Guo et al. (2014) reported that the solubility of $\mathrm{P}$ was $0.6 \%-63 \%$ in the aerosols collected at the Huaniao Island of the East China Sea, and the median value was $21 \%$ in spring. He et al. (2011) studied the atmospheric dry and wet deposition of $\mathrm{P}$ in Singapore and reported that DIP comprised $38 \%$ of TP in aerosols. In the dust samples of this study, however, the P solubility was approximately $8 \%$, which was close to the value of $10 \%$ measured in dust aerosols collected at the Mediterranean coast (Carbo et al., 2005; Herut et al., 2002; Nenes et al., 2011) but was considerably lower than the value of $20 \%$ measured in Asian dust at the coastal site of the East China Sea and in African dust in the western subtropical North Atlantic (Guo et al., 2014; Zamora et al., 2013). There are few available data for P solubility in the marine atmosphere (Hsu et al., 2014; Baker et al., 2006a, b), and the limited data show that the solubility 

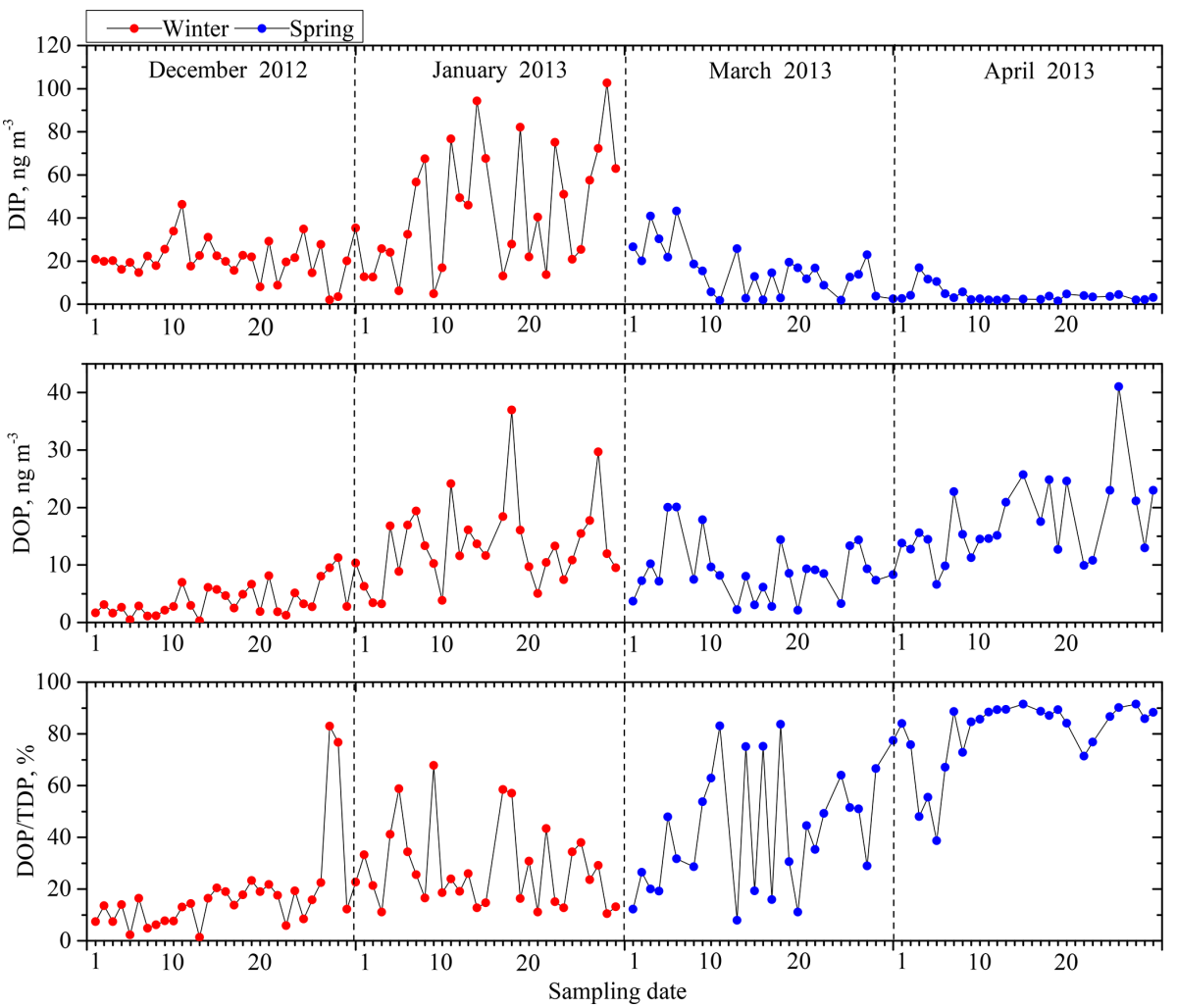

Figure 2. Time series of dissolved inorganic and organic P concentrations (DIP and DOP) and the percentage of DOP in TDP.

of $\mathrm{P}$ in marine aerosols is generally higher than that in coastal aerosols (Table 1).

The ratio of DIP / TP has frequently been used as a proxy for $\mathrm{P}$ solubility in previous studies with no consideration of the contribution of DOP. The fraction of DOP in TDP was approximately $40 \%$ in this study (Fig. 2) and $31 \%$ in the aerosols at the Gulf of Aqaba (Chen et al., 2007). Our DOP results indicate that using the DIP / TP ratio as a proxy for the solubility of P could largely underestimate the real P solubility in aerosols by approximately $30 \%-40 \%$.

Seasonally, the P solubility in winter was $32.9 \pm 16.7 \%$, which was much higher than the value of $21.3 \pm 9.8 \%$ for $P$ solubility in spring (Fig. 1, Table 1). In winter, the $\mathrm{P}$ solubility was negatively correlated with $\mathrm{Al}$ (Table $\mathrm{S} 1$ ) and positively correlated with anthropogenic elements such as $\mathrm{Zn}$, $\mathrm{As}, \mathrm{Cd}$, and $\mathrm{Pb}$ and ions such as nss- $\mathrm{K}^{+}$, nss- $\mathrm{SO}_{4}^{2-}$ and $\mathrm{NO}_{3}^{-}$. The correlations likely result from the effects of crustal and anthropogenic sources, as well as the effects of atmospheric processes on $\mathrm{P}$ solubility. However, in spring, P solubility did not have a clear relationship with anthropogenic source indicators, i.e., $\mathrm{Cd}, \mathrm{As}, \mathrm{Zn}, \mathrm{Pb}, \mathrm{nss}_{-} \mathrm{SO}_{4}^{2-}$ and $\mathrm{NO}_{3}^{-}$, but was still negatively correlated with crustal elements such as $\mathrm{Al}, \mathrm{Fe}$, $\mathrm{Ca}, \mathrm{Mn}$ and $\mathrm{Ba}$. Therefore, the variation in $\mathrm{P}$ solubility could also be caused by changes in the dominant aerosol particles.

\subsection{Factors influencing $P$ solubility}

\subsubsection{Aerosol sources and mineral dust loading}

Mineral dust aerosols are generally considered the dominant sources of atmospheric TP (Mahowald et al., 2008). As mentioned above, TP had statistically significant correlations with the contents of mineral elements. We choose $\mathrm{Al}$ as the indicator of the mineral origin of aerosols to investigate the effect of aerosol sources and dust loading on $\mathrm{P}$ solubility. Because the content of $\mathrm{Al}$ in mineral particles is stable, $\mathrm{Al}$ has few sources other than mineral particles (Arimoto et al., 2006). TP showed a strong linear relationship with total $\mathrm{Al}$ (Fig. 3a), and all data points were significantly above the line of $\mathrm{P} / \mathrm{Al}=0.013$, which is the ratio of $\mathrm{P}$ to $\mathrm{Al}$ in the crust (Taylor, 1964). Therefore, there were sources of TP other than the crustal source.

The concentration of non-dust $\mathrm{P}\left(\mathrm{P}_{\mathrm{nd}}\right)$ was estimated with the following formula (2):

$\mathrm{P}_{\mathrm{nd}}=\mathrm{TP}-\mathrm{TAl} \cdot \frac{\mathrm{P}_{\text {crust }}}{\mathrm{Al}_{\text {crust }}}$,

where TP is the total $\mathrm{P}$ concentration, $\mathrm{TAl}$ is the total $\mathrm{Al}$ concentration and $\mathrm{P}_{\text {crust }} / \mathrm{Al}_{\text {crust }}$ is the ratio of $\mathrm{P}$ to $\mathrm{Al}$ in continental crust. We consider the excess $\mathrm{P}$ relative to $\mathrm{P} / \mathrm{Al}$ in the mineral dust to represent the fraction of $\mathrm{P}$ derived from anthropogenic activities because atmospheric $\mathrm{P}$ is mainly 

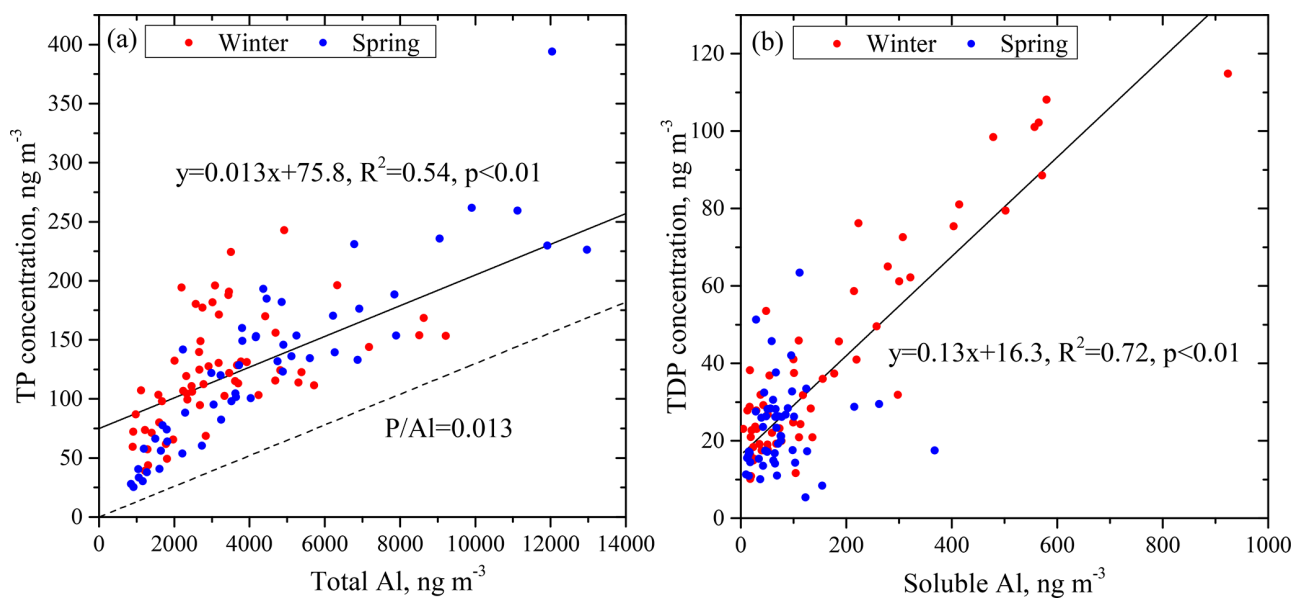

Figure 3. Correlations of $\mathrm{TP}$ with total $\mathrm{Al}$ (a) and $\mathrm{TDP}$ with soluble $\mathrm{Al}$ (b). The line of $\mathrm{P} / \mathrm{Al}=0.013$ represents the ratio of $\mathrm{P}$ to $\mathrm{Al}$ in the crust.

caused by anthropogenic activities and natural dust in addition to a small fraction of biological P (Wang et al., 2015). Results show that the maximum concentration of anthropogenic $\mathrm{P}$ was about $75.8 \mathrm{ng} \mathrm{m}^{-3}$, as shown by the intercept of the regression line in Fig. 3a, and the maximum contribution of anthropogenic P to TP was as high as $60 \%$ on average. Part of the TP was also from primary biological sources, especially in spring. Therefore, the value $60 \%$ overestimates the $\mathrm{P}$ contribution of anthropogenic sources.

Aerosol P from anthropogenic sources usually has a higher solubility than that from mineral sources. The reason is that anthropogenic P tends to associate loosely with particulates, dissolve more readily than mineral $\mathrm{P}$ and, consequently, interact easily with acid gases to produce more bioavailable $\mathrm{P}$ (Herut et al., 2002; Baker et al., 2006a, b; Anderson et al., 2010; Hsu et al., 2014; Herbert et al., 2018). Our results indicate that the $\mathrm{P}$ solubility was approximately $35 \%$ in the aerosols when the fraction of anthropogenic $\mathrm{P}$ in the TP was more than $70 \%$. In contrast, the value was approximately $15 \%$ in the aerosols when the fraction of anthropogenic $\mathrm{P}$ in the TP was less than $50 \%$. Therefore, the high fraction of $\mathrm{P}$ from anthropogenic sources in the TP in winter is likely one reason that winter $\mathrm{P}$ solubility was higher than spring $\mathrm{P}$ solubility.

Total dissolved $\mathrm{P}$ also showed a correlation with soluble $\mathrm{Al}$ (Fig. 3b). The slope of the regression line between $\mathrm{P}$ and $\mathrm{Al}$ was 0.13 in the soluble fraction, which was higher than that in the total fraction. This result is reasonable because the solubility of $\mathrm{P}$ is considerably higher than that of $\mathrm{Al}$ (Hsu et al., 2014) and/or because anthropogenic sources directly contribute to more soluble-fraction P (Anderson et al., 2010).

The P solubility and total $\mathrm{Al}$ concentration (as dust loading) displayed an inverse power-law relationship (Fig. 4). The data in the South China Sea and the East China Sea from the literature also conform to this fitting relationship (Hsu et al., 2014; Guo et al., 2014), except for the data observed over

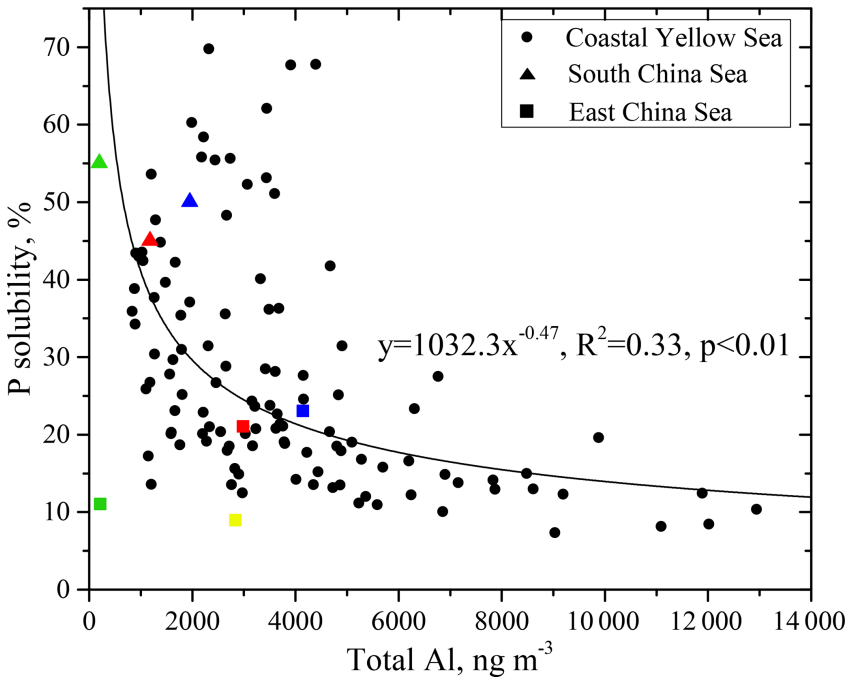

Figure 4. Relationships of $\mathrm{P}$ solubility against total Al. Data in the South China Sea are from Hsu et al. (2014) (triangles), and data in the East China Sea are from Guo et al. (2014) (squares). Different color symbols are used to highlight different observation periods. The green and red triangles represent the averages of observations in the South China Sea during cruises in February-March 2013 and June 2013, respectively; the blue triangles represent the observed values of the samples affected by biomass burning in the June cruise. The blue, green, yellow and red squares represent the averages of observations over Huaniao Island in the East China Sea during April, July-August and November-December 2010, and March 2011, respectively.

the East China Sea in July and August 2010, when the air mass was mainly from the open ocean (Guo et al., 2014). These results indicate the potential to extrapolate the discussion of this study to the marginal sea areas of eastern China. A characteristic inverse relationship with $\mathrm{Al}$ has also been observed for aerosol Fe over large regions of the global ocean 
(Sholkovitz et al., 2012). Similarly, the relationship between $\mathrm{P}$ and $\mathrm{Al}$ can be attributed to the mixing of two end-members, i.e., mineral dust with a low $\mathrm{P}$ solubility and high $\mathrm{Al}$ loading and anthropogenic aerosols with a high $\mathrm{P}$ solubility and low Al loading.

For the samples with high Al loading, i.e., a concentration of more than $6000 \mathrm{ng} \mathrm{m}^{-3}$, the $\mathrm{P}$ solubility was frequently below $15 \%$. The TP in these samples was mainly derived from mineral dust, which contributed more than $60 \%$ of the TP. The $72 \mathrm{~h}$ back trajectories for samples with high Al loading indicate that the air masses originated from the arid and semiarid areas in the inland Asian continent, where aerosol particles are dominated by natural mineral dust (Fig. S2). Moreover, the air masses were rapidly transported in the elevated layer; the average highest altitude was approximately $2600 \mathrm{~m}$ during the transport of these air masses, and the average transport speed in the $36 \mathrm{~h}$ before arrival at Qingdao was $47 \mathrm{~km} \mathrm{~h}^{-1}$. These air masses passed populated areas in a short period of time and experienced little interference by anthropogenic pollutants; therefore, the high Al loading and low P solubility end-member exhibited a relatively high mineral dust characteristic.

For samples with a low Al loading below $2000 \mathrm{ng} \mathrm{m}^{-3}$, the $\mathrm{P}$ solubility was usually above $25 \%$, and the average P solubility was approximately $35 \%$. The TP in these samples was mainly from anthropogenic sources, which contributed approximately $70 \%$ of TP. The $72 \mathrm{~h}$ back trajectories for the samples indicated that, very different from the air masses with high Al loading, these air masses moved slowly at a low altitude (Fig. S3). The highest altitude during the air mass transport was approximately $1300 \mathrm{~m}$ on average, and the transport speed in the $36 \mathrm{~h}$ prior to arrival at Qingdao was an average of $23 \mathrm{~km} \mathrm{~h}^{-1}$. The air masses passed populated areas and were influenced directly by anthropogenic pollutants. Therefore, the low Al loading and high P solubility end-member exhibited a relatively high concentration of anthropogenic aerosols.

The inverse relationship between $\mathrm{P}$ solubility and total $\mathrm{Al}$ loading may also reflect the effects of particle size, similar to aerosol Fe (Baker and Jickells, 2006; Baker and Croot, 2010). A dust population with a small modal size has a large surface area, which more efficiently serves as a sink for acidic constituents and easily leads to an increase in the solubility of dust-derived elements. There was a clear linear correlation between the P solubility and the specific surface areas of the aerosols, and the solubility increased with decreases in the particle size (Fig. 5). This result is consistent with previously reported results on this subject (Baker et al. 2006a, b).

\subsubsection{Atmospheric acidification processing}

Some data points, for $\mathrm{P}$ solubility against total $\mathrm{Al}$ and the specific surface area, deviated from the fitting curves (Figs. 4, 5), and most of these points presented in the samples contain-

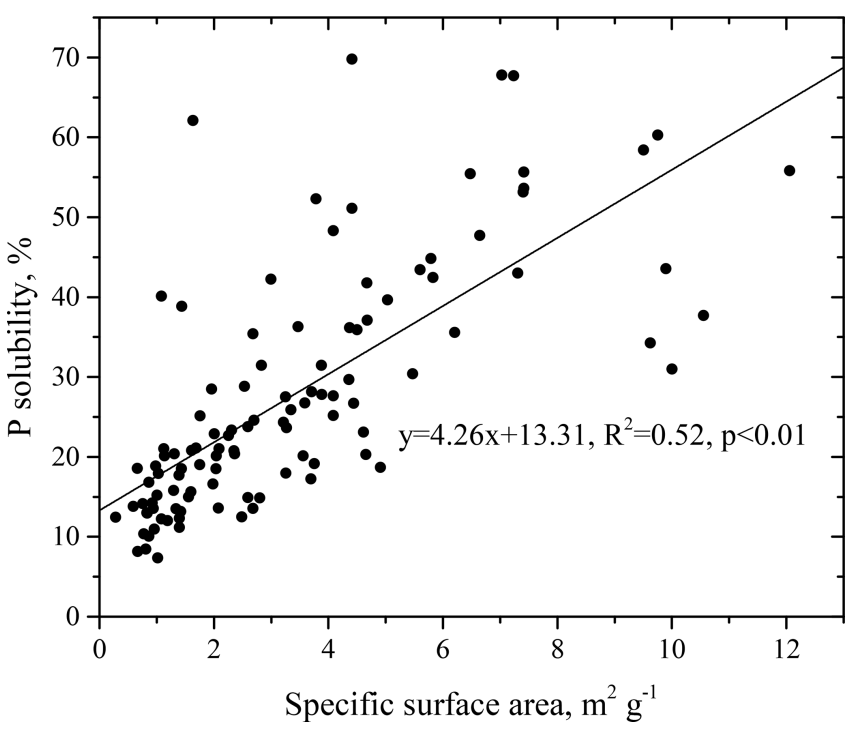

Figure 5. Relationships between $P$ solubility and the specific surface area of particles.

ing more anthropogenic particles. This result suggests that the two end-member mixtures of mineral dust and anthropogenic particles could not completely explain the P solubility. Nenes et al. (2011) proposed that the atmospheric acidification processes that mineral aerosols experience could be a primary mechanism to enhance aerosol $\mathrm{P}$ solubility. Nenes et al. (2011) found that the solubility of $P$ in the Sahara surface soil and dust aerosols was 10-40 times higher after acid treatment using a $\mathrm{pH} 2$ sulfuric acid solution. Stockdale et al. (2016) also found that the amount of $\mathrm{P}$ dissolved is directly proportional to the amount of $\mathrm{H}^{+}$consumed at $\mathrm{H}^{+}>10^{-4} \mathrm{~mol} \mathrm{~g}^{-1}$ of dust. Similar processes have been demonstrated to affect the fraction of soluble Fe in mineral dust (e.g., Baker and Croot, 2010; Shi et al., 2015; Longo et al., 2016; Li et al., 2017). However, a corroboration of direct observational data on aerosol $\mathrm{P}$ solubility remains insufficient. Hsu et al. (2010) reported that soluble P correlated well with nss- $\mathrm{SO}_{4}^{2-}$ and $\mathrm{NO}_{3}^{-}$in aerosols collected over the East China Sea and implied that the dissolution of aerosol $\mathrm{P}$ was enhanced by the presence of acidic constituents. In the present study, we confirmed that both soluble $\mathrm{P}$ and $\mathrm{P}$ solubility were statistically correlated with nss- $\mathrm{SO}_{4}^{2-}, \mathrm{NO}_{3}^{-}$and $\mathrm{Cl}^{-}$, indicating the potential enhancement of the dissolution of aerosol $\mathrm{P}$ by acid processing and the consequent increase in $\mathrm{P}$ solubility.

Following Hsu et al. (2014), who used the ratio of acids to total Fe to investigate the influence of aerosol acidification on the Fe solubility, we use the ratio of acids / total P to investigate the influence of aerosol acidification on the $\mathrm{P}$ solubility. We found that both the nss- $\mathrm{SO}_{4}^{2-} / \mathrm{TP}$ and $\mathrm{NO}_{3}^{-} / \mathrm{TP}$ molar ratios were statistically correlated with $\mathrm{P}$ solubility in all samples $(r=0.36, p<0.01)$ (Fig. 6a, b). In contrast, there was no such relationship between the $\mathrm{Cl}^{-} / \mathrm{TP}$ molar ra- 

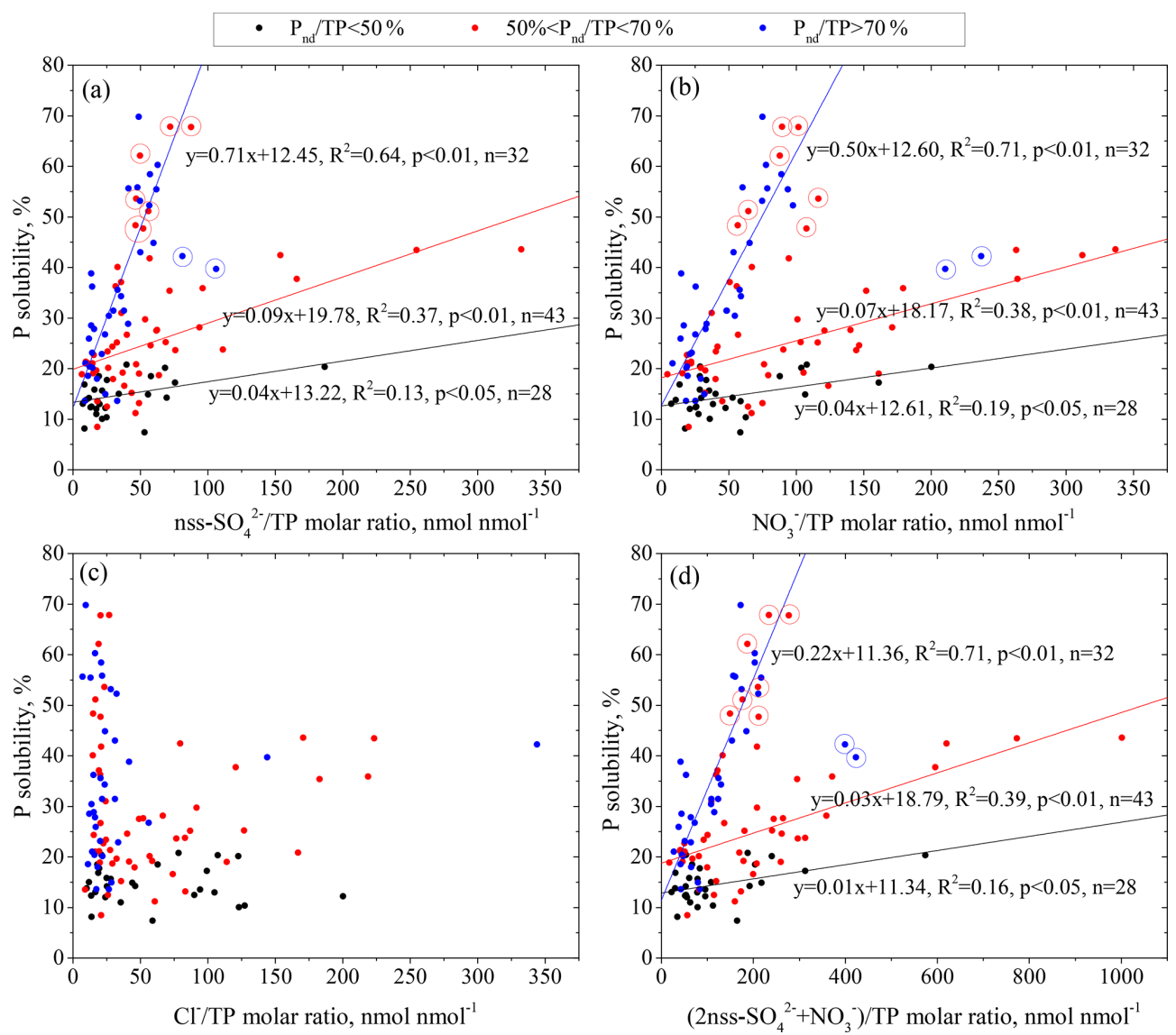

Figure 6. Correlations between $\mathrm{P}$ solubility and the nss- $\mathrm{SO}_{4}^{2-} / \mathrm{TP}$ molar ratio (a), $\mathrm{NO}_{3}^{-} / \mathrm{TP}$ molar ratio (b), $\mathrm{Cl}^{-} / \mathrm{TP}^{\mathrm{molar}}$ ratio (c) and (nss- $\mathrm{SO}_{4}^{2-}+\mathrm{NO}_{3}^{-}$) / TP neq / molar ratio $(\mathbf{d})$ in aerosols with different relative contributions of non-dust $\mathrm{P}\left(\mathrm{P}_{\mathrm{nd}}\right)$ to $\mathrm{TP}\left(\mathrm{P}_{\mathrm{nd}} / \mathrm{TP}\right)$. Data points within the circle were not included in the regression fitting.

tio and P solubility (Fig. 6c). The combination of nss- $\mathrm{SO}_{4}^{2-}$ and $\mathrm{NO}_{3}^{-}$, the two major acidic constituents in atmospheric aerosols, was further examined (Fig. 6d). The samples were classified into three groups based on the relative contribution of non-dust $\mathrm{P}\left(\mathrm{P}_{\mathrm{nd}}\right)$ to TP $\left(\mathrm{P}_{\mathrm{nd}} / \mathrm{TP}\right)$ (Fig. 6). The P solubility increases with the acidification degree (the molar ratio of $\left[2 \mathrm{nss}-\mathrm{SO}_{4}^{2-}+\mathrm{NO}_{3}^{-}\right] / \mathrm{TP}$ ) of aerosols. However, the $\mathrm{P}$ solubility versus the acid / TP ratio followed different regression curves corresponding to the ranges of $\mathrm{P}_{\text {nd }} / \mathrm{TP}$, e.g., the slope of 0.22 in samples with $\mathrm{P}_{\mathrm{nd}} / \mathrm{TP}>70 \%$ and of 0.01 in samples with $\mathrm{P}_{\text {nd }} / \mathrm{TP}<50 \%$. The aerosol specific surface area in the samples with $\mathrm{P}_{\text {nd }} / \mathrm{TP}>70 \%$ was $4.54 \mathrm{~m}^{2} \mathrm{~g}^{-1}, 3$ times larger than that of the samples with $\mathrm{P}_{\text {nd }} / \mathrm{TP}<50 \%$, i.e., $1.45 \mathrm{~m}^{2} \mathrm{~g}^{-1}$. The samples with $\mathrm{P}_{\mathrm{nd}} / \mathrm{TP}>70 \%$ had more areas to react with acidic constituents, leading to more TDP. However, this explanation can only explain approximately $15 \%$ of the difference between the slopes of the two fitted curves. The remaining difference should be due to the different natures of $\mathrm{P}$ in the aerosols; therefore, $\mathrm{P}$ in anthropogenic particles should be more susceptible to acidic processing than that in natural mineral dust. Notably, the an- thropogenic $\mathrm{P}$ in the aerosols had an intrinsically higher solubility than the soil-derived mineral P (Baker et al., 2006a, b). This means that changes in the dominant aerosol particles could also cause differences between the slopes of the two fitting curves. Hsu et al. (2014) also found that the relationship of aerosol P solubility vs. $\sum$ (nss-sulfate + nitrate) $/ \mathrm{TP}$ in a February-March cruise and June cruise over the South China Sea followed two regression curves. They attributed the discrepancy to the discernible dominance of the respective sources vs. the susceptibility to acidic processes.

Two data points largely deviated from the fitting curve of the $\mathrm{P}_{\mathrm{nd}} / \mathrm{TP}>70 \%$ samples (Fig. 6). Analysis of the characteristics of the two samples revealed that their DOP content was relatively high and was approximately $21 \%$ of the TP, while the DOP value for other samples was $7 \%$ of the TP. Aerosol organic $\mathrm{P}$ is originally associated with organic matter in biological sources rather than anthropogenic sources (Chen et al., 2006). Kanakidou et al. (2012) provided an organic phosphorus budget showing a relatively large marine source (almost $80 \%$ with large uncertainties in magnitude). The organic $\mathrm{P}$ in the two samples with a high $\mathrm{Cl}^{-} / \mathrm{TP}$ molar 


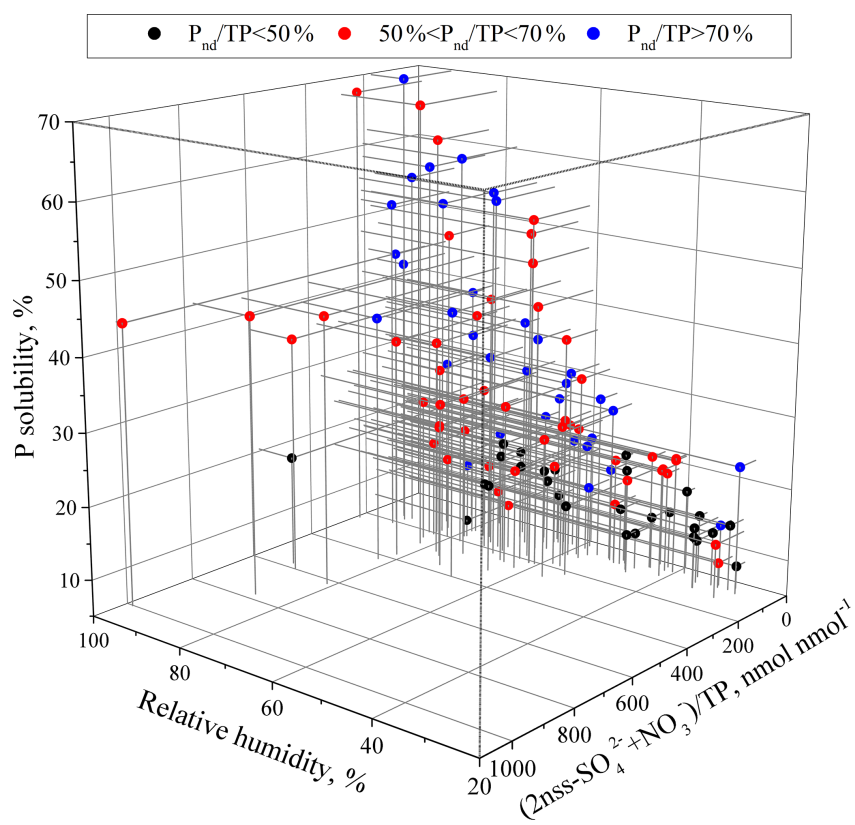

Figure 7. Relationships of $\mathrm{P}$ solubility with the relative humidity and acidification degree in aerosols with different ranges of $\mathrm{P}_{n d} / \mathrm{TP}$.

ratio might be, at least partly, caused by the contribution from marine biological sources in addition to terrestrial biological sources. Therefore, the contribution of anthropogenic P to $\mathrm{TP}$ was significantly overestimated in the two samples due to the high organic $\mathrm{P}$ content. In addition, insoluble organic $\mathrm{P}$ could be converted to DOP due to the uptake of oxidants and the formation of large chains of soluble multifunctional groups (Ariya et al., 2009; Myriokefalitakis et al., 2016). The conversion mechanism of organic $\mathrm{P}$ from insoluble to soluble, which is different from the acid solubilization of $\mathrm{P}$, may also be responsible for the deviation of the two samples from the fitted curve.

\subsubsection{Relative humidity and the coordinated effect of aerosol sources and acidity}

The data points of $\mathrm{P}$ solubility against acids / total $\mathrm{P}$ for the samples of $50 \%<\mathrm{P}_{\mathrm{nd}} / \mathrm{TP}<70 \%$ were frequently between the two fitted curves of $\mathrm{P}_{\text {nd }} / \mathrm{TP}>70 \%$ and $\mathrm{P}_{\text {nd }} / \mathrm{TP}<50 \%$ (Fig. 6) and had a statistically significant correlation at the $99 \%$ confidence $(r=0.383, p=0.006)$. Some data points largely deviated from the fitted curves, showing high P solubility at low degrees of acidification. We focused on the seven deviating data points at $\mathrm{P}$ solubility $>45 \%$ and acid / TP $<200 \mathrm{nmol} \mathrm{nmol}^{-1}$ (the $\mathrm{P}_{\text {nd }} / \mathrm{TP}$ in the samples was approximately $60 \%$, and these data points are highlighted in red circles in Fig. 6). The RH during the collection of these samples was approximately $80 \%$ on average, much higher than the value of $65 \%$ for the other samples in this group. Elevated $\mathrm{RH}$ can result in particle phase conversion from a semisolid to a liquid state (Liu et al., 2017). The presence of aqueous layers on the aerosol particles can enhance insoluble trace elements, such as Fe, to dissolve under acidic conditions (Shi et al., 2015). This was likely caused by the acidification of particles as they cycled from cloud droplets to wet aerosols and back (Nenes et al., 2010; Stockdale et al., 2016). We further investigated the relationship of RH with P solubility and confirmed that the two factors showed a significant correlation $(r=0.62, p<0.01)$, suggesting the significance of RH as one of the factors influencing aerosol P solubility.

The coordinated effect of RH, aerosol sources and acidity on $\mathrm{P}$ solubility was further investigated (Fig. 7). Because the threshold of $\mathrm{RH}$ for particle conversion from the semisolid to liquid state was frequently approximately $60 \%$ (Liu et al., 2017), we used $60 \% \mathrm{RH}$ as the threshold of wet aerosol formation. The $\mathrm{P}$ solubility was frequently lower than $30 \%$ when $\mathrm{RH}<60 \%$, even in samples with a relatively high acidification degree or a large fraction of anthropogenic $\mathrm{P}$. On average, the P solubility was approximately $13 \%$ in the aerosols of $\mathrm{P}_{\text {nd }} / \mathrm{TP}<50 \%$, while the value was approximately $21 \%$ in the aerosols of $\mathrm{P}_{\text {nd }} / \mathrm{TP}>50 \%$. The aerosol acidification had little effect on the P solubility when the RH was less than $60 \%$.

At $\mathrm{RH}>60 \%$, the $\mathrm{P}$ solubility ranged from approximately $10 \%$ to approaching $70 \%$. To examine the influence of acidity or humidity on $\mathrm{P}$ solubility, the samples were classified into two groups according to the acidification degree of $150 \mathrm{nmol} \mathrm{nmol}^{-1}$, which was close to the average acidification degree of all aerosol samples. For the aerosols of $\mathrm{P}_{\mathrm{nd}} / \mathrm{TP}<50 \%$, the $\mathrm{P}$ solubility was higher than $13 \%$. Under similar acidic conditions, $\mathrm{P}$ solubility increased with the increase in RH. However, the increase was not significant and was only approximately $2 \%$ when the RH changed from $<60 \%$ to $>60 \%$. For the aerosols of $50 \%<\mathrm{P}_{\text {nd }} / \mathrm{TP}<70 \%$, the $\mathrm{P}$ solubility was frequently higher than $21 \%$. P solubility increased with the increase in RH. When RH increased from less than $60 \%$ to more than $60 \%$, the P solubility increased from, on average, $20 \%$ to $30 \%$ under the acid $/ \mathrm{TP}<150 \mathrm{nmol} \mathrm{nmol}^{-1}$ condition and approximately $20 \%$ to $35 \%$ under the acid $/ \mathrm{TP}>150 \mathrm{nmol} \mathrm{nmol}^{-1}$ condition. For the aerosols of $\mathrm{P}_{\mathrm{nd}} / \mathrm{TP}>70 \%$, the $\mathrm{P}$ solubility was higher than $21 \%$. Under similar acid conditions, the P solubility was in the range of $40 \%-60 \%$ at RH $>80 \%$ and in the range of $20 \%-40 \%$ at $60 \%<\mathrm{RH}<80 \%$.

Overall, the enhancement of $\mathrm{P}$ solubility by RH increase in the mineral aerosols was much lower than in the anthropogenic aerosols, in which $\mathrm{P}$ was more susceptible to acidification, e.g., at $\mathrm{RH}>60 \%$. All of these results indicate that $\mathrm{RH}$ is also likely one of the factors significantly impacting aerosol P solubility; high humidity could facilitate the dissolution of aerosol $\mathrm{P}$ under acidic conditions and hence increase its solubility. 


\section{Conclusions}

In this study, we quantified the levels and seasonal variability in TP, TDP, DIP, DOP and P solubility at Qingdao, a coastal city of the Yellow Sea, China, aiming to demonstrate the solubility of $\mathrm{P}$ in aerosol particles from Asian continental outflow. The P solubility in Qingdao aerosols was $7.3 \%-69.8 \%$, which overlapped with the range of values reported in other coastal areas. P solubility in winter was significantly higher than that in spring, which was related to the aerosol sources, atmospheric acidification processes and ambient RH. Our data indicated that the P in aerosols from anthropogenic sources had a higher solubility than the $\mathrm{P}$ in aerosols from mineral sources. The acid processing associated with sulfate and nitrate formation could increase the solubility of $\mathrm{P}$, with $\mathrm{P}$ from anthropogenic sources demonstrating a greater susceptibility to acid processing than $\mathrm{P}$ from mineral dust. In addition, we found that DOP has an important contribution to dissolved $\mathrm{P}$, with an average contribution of $40 \%$ in some cases. Furthermore, ambient RH was an important factor influencing $\mathrm{P}$ solubility. At $\mathrm{RH}<60 \%$, it was difficult for $\mathrm{P}$ solubility to exceed $30 \%$, even with a high aerosol acidity and anthropogenic $\mathrm{P}$ contribution. High $\mathrm{RH}$ levels increased the dissolution of aerosol $\mathrm{P}$ to a greater degree under acidic conditions, consequently increasing $\mathrm{P}$ solubility. These results imply and support that anthropogenic inputs could provide more soluble $\mathrm{P}$ to the ocean via the atmosphere, thus increasing the bioavailable $\mathrm{P}$ in the ocean and potentially impacting ocean biogeochemistry.

Data availability. The data of this paper are available upon request (Jinhui Shi, engroup@ouc.edu.cn).

Supplement. The supplement related to this article is available online at: https://doi.org/10.5194/acp-19-847-2019-supplement.

Author contributions. JS designed the research. NW conducted the sample analysis. JS, NW and DZ wrote the paper. JS and DZ revised the paper. NW prepared all the figures. HG, ARB and XY provided useful comments. All authors contributed toward improving the paper.

Competing interests. The authors declare that they have no conflict of interest.

Acknowledgements. We thank Xiaoyu Ben for his assistance in sample collection and part of the chemical analysis. We appreciate the two anonymous reviews and the editor for their helpful comments and suggestions, due to which the readership largely increased compared to the initial submission. This research received support from the National Key Research and
Development Program of China (2016YFC0200504), the National Nature Science Foundation of China (41876131) and the National Key Basic Research Program of China (2014CB9537001).

Edited by: Maria Kanakidou

Reviewed by: two anonymous referees

\section{References}

Anderson, L. D., Faul, K. L., and Paytan, A.: Phosphorus associations in aerosols: What can they tell us about $\mathrm{P}$ bioavailability?, Mar. Chem., 120, 44-56, 2010.

Arimoto, R., Kim, Y. J., Kim, Y. P., Quinn, P. K., Bates, T. S., Anderson, T. L., Gong, S., Uno, I., Chin, M., Huebert, B. J., Clarke, A. D., Shinozuka, Y., Weber, R. J., Anderson, J. R., Guazzotti, S. A., Sullivan, R. C., Sodeman, D. A., Prather, K. A., and Sokolik, I. N.: Characterization of Asian dust during ACE-Asia, Global Planet. Change, 52, 23-56, 2006.

Ariya, P. A., Sun, J., Eltouny, N. A., Hudson, E. D., Hayes, C. T., and Kos, G.: Physical and chemical characterization of bioaerosols - Implications for nucleation processes, Int. Rev. Phys. Chem., 28, 1-32, https://doi.org/10.1080/01442350802597438, 2009.

Baker, A. R. and Croot, P. L.: Atmospheric and marine controls on aerosol iron solubility in seawater, Mar. Chem., 120, 4-13, 2010.

Baker, A. R. and Jickells, T. D.: Mineral particle size as a control on aerosol iron solubility, Geophys. Res. Lett., 33, L17608, https://doi.org/10.1029/2006GL026557, 2006.

Baker, A. R., French, M., and Linge, K. L.: Trends in aerosol nutrient solubility along a west-east transect of the Saharan dust plum, Geophys. Res. Lett., 33, L07805, https://doi.org/10.1029/2005GL024764, 2006a.

Baker, A. R., Jickells, T. D., Witt, M., and Linge, K. L.: Trends in the solubility of iron, aluminium, manganese and phosphorus in aerosol collected over the Atlantic Ocean, Mar. Chem., 98, 4358, 2006b.

Carbo, P., Krom, M. D., Homoky, W. B., Benning, L. G., and Herut, B.: Impact of atmospheric deposition on $\mathrm{N}$ and $\mathrm{P}$ geochemistry in the southeastern Levantine basin, Deep-Sea Res. Pt. II, 52, 3041-3053, 2005.

Chen, Y., Street, J., and Paytan, A.: Comparison between pure-water and seawater soluble nutrient concentrations of aerosols from the Gulf of Aqaba, Mar. Chem., 101, 141-152, 2006.

Chen, Y., Mills, S., Street, J., Golan, D., Post, A., Jacobson, M., and Paytan, A.: Estimates of atmospheric dry deposition and associated input of nutrients to Gulf of Aqaba seawater, J. Geophys. Res., 112, D04309, https://doi.org/10.1029/2006JD007858, 2007.

Elser, J. J., Bracken, M. E. S., Cleland, E. E., Gruner, D. S., Harpole, W. S., Hillebrand, H., Ngai, J. T., Seabloom, E. W., Shurin, J. B., and Smith, J. E.: Global analysis of nitrogen and phosphorus limitation of primary producers in freshwater, marine and terrestrial ecosystems, Ecol. Lett., 10, 1135-1142, 2007.

Griffin, D. W., Kubilay, N., Kocak, M., Gray, M. A., Borden, T. C. and Shinn, E. A.: Airborne desert dust and aeromicrobiology over the Turkish Mediterranean coastline, Atmos. Environ., 41, 4050-4062, 2007. 
Guo, L., Chen, Y., Wang, F., Meng, X., Xu, Z., and Zhuang, G.: Effects of Asian dust on the atmospheric input of trace elements to the East China Sea, Mar. Chem., 163, 19-27, 2014.

Hara, K. and Zhang, D.: Bacterial abundance and viability in longrange transported dust, Atmos. Environ., 47, 20-25, 2012.

He, J., Balasubramanian, R., Burger, D. F., Hicks, K., Kuylenstierna, J. C., and Palani, S.: Dry and wet atmospheric deposition of nitrogen and phosphorus in Singapore, Atmos. Environ., 45, 2760-2768, 2011.

Herbert, R. J., Krom, M. D., Carslaw, K. S., Stockdale, A., Mortimer, R. J. G., Benning, L. G., Pringle, K., and Browse, J.: The effect of atmospheric acid processing on the global deposition of bioavailable phosphorus from dust, Global Biogeochem. Cy., 32, 1-19, https://doi.org/10.1029/2018GB005880, 2018.

Herut, B., Collier, R. W., and Krom, M. D.: The role of dust in supplying nitrogen and phosphorus to the southeast Mediterranean, Limnol. Oceanogr., 47, 870-878, 2002.

Hsu, S.-C., Wong, G. T. F., Gong, G. C., Shiah, F. K., Huang, Y. T., Kao, S. J., Tsai, F., Lung, S. C. C., Lin, F. J., Lin, I. I., Hung, C. C., and Tseng, C. M.: Sources, solubility, and dry deposition of aerosol trace elements over the East China Sea, Mar. Chem., 120, 116-127, https://doi.org/10.1016/j.marchem.2008.10.003, 2010.

Hsu, S.-C., Gong, G.-C., Shiah, F.-K., Hung, C.-C., Kao, S.-J., Zhang, R., Chen, W.-N., Chen, C.-C., Chou, C. C.-K., Lin, Y.C., Lin, F.-J., and Lin, S.-H.: Sources, solubility, and acid processing of aerosol iron and phosphorous over the South China Sea: East Asian dust and pollution outflows vs. Southeast Asian biomass burning, Atmos. Chem. Phys. Discuss., 14, 2143321472, https://doi.org/10.5194/acpd-14-21433-2014, 2014.

Izquierdo, R., Benítez-Nelson, C. R., Masqué, P., Castillo, S., Alastuey, A., and Àvila, A.: Atmospheric phosphorus deposition in a near-coastal rural site in the NE Iberian Peninsula and its role in marine productivity, Atmos. Environ., 49, 361-370, 2012.

Joos, H., Madonna, E., Witlox, K., Ferrachat, S., Wernli, H., and Lohmann, U.: Effect of anthropogenic aerosol emissions on precipitation in warm conveyor belts in the western North Pacific in winter - a model study with ECHAM6-HAM, Atmos. Chem. Phys., 17, 6243-6255, https://doi.org/10.5194/acp17-6243-2017, 2017.

Kanakidou, M., Duce, R. A., Prospero, J. M., Baker, A. R., BenitezNelson, C., Dentener, F. J., and Sarin, M.: Atmospheric fluxes of organic $\mathrm{N}$ and $\mathrm{P}$ to the global ocean, Global Biogeochem. Cy., 26, GB3026, https://doi.org/10.1029/2011GB004277, 2012.

Kanakidou, M., Myriokefalitakis, S., and Tsigaridis, K.: Aerosols in atmospheric chemistry and biogeochemical cycles of nutrients, Environ. Res. Lett., 13, 063004, https://doi.org/10.1088/17489326/aabcdb, 2018.

Karl, D. M. and Tien, G.: Temporal variability in dissolved phosphorus concentrations in the subtropical North Pacific Ocean, Mar. Chem., 56, 77-96, 1997.

Kim, I. N., Lee, K., Gruber, N., Karl, D. M., Bullister, J. L., Yang, S., and Kim, T. W.: Increasing anthropogenic nitrogen in the North Pacific Ocean, Science, 346, 1102-1106, https://doi.org/10.1126/science.1258396, 2014.

Kim, S. K., Chang, K. I., Kim, B., and Cho, Y. K.: Contribution of ocean current to the increase in $\mathrm{N}$ abundance in the northwestern Pacific marginal seas, Geophys. Res. Lett., 40, 143-148, https://doi.org/10.1029/2012GL054545, 2013.
Kodama, T., Igeta, Y., Kuga, M., and Abe, S.: Long-term decrease in phosphate concentrations in the surface layer of the southern Japan Sea, J. Geophys. Res., 121, 7845-7856, https://doi.org/10.1002/2016JC012168, 2016.

Li, W., Xu, L., Liu, X., Zhang, J., Lin, Y., Yao, X., Gao, H., Zhang, D., Chen, J., Wang, W., Harrison, R. M., Zhang, X., Shao, L., Fu, P., Nenes, A., and Shi, Z.: Air pollution-aerosol interactions produce more bioavailable iron for ocean ecosystems, Sci. Adv., 3, e1601749, https://doi.org/10.1126/sciadv.1601749, 2017.

Liu, Y., Wu, Z., Wang, Y., Xiao, Y., Gu, F., Zheng, J., Tan, T., Shang, D., Wu, Y., Zeng, L., Hu, M., Bateman, A. P., and Martin, S. T. Submicrometer particles are in the liquid state during heavy haze episodes in the urban atmosphere of Beijing, China, Environ. Sci. Technol. Lett., 4, 427-432, 2017.

Longo, F., Feng, Y., Lai, B., Landing, W. M., Shelley, R. U., Nenes, A., Mihalopoulos, N., Violaki, K., and Ingall, E. D.: Influence of atmospheric processes on the solubility and composition of iron in saharan dust, Environ. Sci. Technol., 50, 6912-6920, 2016.

Lyu, Y. L., Liu, L. Y., Guo, L. L., Yang, Y. Y., Qu, Z. Q., Hu, X., and Zhang, G. M.: Deposited atmospheric dust as influenced by anthropogenic emissions in northern China, Environ. Monit. Assess., 189, 1-14, https://doi.org/10.1007/s10661-017-6093-1, 2017.

Mackey, K. R. M., Mioni, C. E., Ryan, J. P., and Paytan, A.: Phosphorus cycling in the red tide incubator region of Monterey Bay in response to upwelling, Front. Microbiol., 3, 1-14, https://doi.org/10.3389/fmicb.2012.00033, 2012a.

Mackey, K. R. M., Roberts, K., Lomas, M. W., Saito, M. A., Post, A. F., and Paytan, A.: Enhanced Solubility and Ecological Impact of Atmospheric Phosphorus Deposition upon Extended Seawater Exposure, Environ. Sci. Technol., 46, 10438-10446, 2012 b.

Mahowald, N., Jickells, T. D., Baker, A. R., Artaxo, P., BenitezNelson, C. R., Bergametti, G., Bond, T. C., Chen, Y., Cohen, D. D., Herut, B., Kubilay, N., Losno, R., Luo, C., Maenhaut, W., McGee, K. A., Okin, G. S., Siefert, R. L., and Tsukuda, S.: Global distribution of atmospheric phosphorus sources, concentrations and deposition rates, and anthropogenic impacts, Global Biogeochem. Cy., 22, GB4026, https://doi.org/10.1029/2008GB003240, 2008.

Myriokefalitakis, S., Nenes, A., Baker, A. R., Mihalopoulos, N., and Kanakidou, M.: Bioavailable atmospheric phosphorous supply to the global ocean: a 3-D global modeling study, Biogeosciences, 13, 6519-6543, https://doi.org/10.5194/bg-13-6519-2016, 2016.

Nenes, A., Krom, M. D., Mihalopoulos, N., Van Cappellen, P., Shi, Z., Bougiatioti, A., Zarmpas, P., and Herut, B.: Atmospheric acidification of mineral aerosols: a source of bioavailable phosphorus for the oceans, Atmos. Chem. Phys., 11, 6265-6272, https://doi.org/10.5194/acp-11-6265-2011, 2011.

Paytan, A. and McLaughlin, K.: The oceanic phosphorus cycle, Chem. Rev., 107, 563-576, 2007.

Peñuelas, J., Poulter, B., Sardans, J., Ciais, P., Velde, M., Bopp, L., Boucher, O., Godderis, Y., Hinsinger, P., Llusia, J., Nardin, E., Vicca, S., Obersteiner, M., and Janssens, I. A.: Humaninduced nitrogen-phosphorus imbalances alter natural and managed ecosystems across the globe, Nat. Commun., 4, 2934, https://doi.org/10.1038/ncomms3934, 2013.

Qi, J., Liu, X., Yao, X., Zhang, R., Chen, X., Lin, X., Gao, H., and Liu, R.: The concentration, source and deposition flux of ammonium and nitrate in atmospheric particles during dust events at a 
coastal site in northern China, Atmos. Chem. Phys., 18, 571-586, https://doi.org/10.5194/acp-18-571-2018, 2018.

Shi, J. H., Gao, H. W., Zhang, J., Tan, S. C., Ren, J. L., Liu, C. G., Liu, Y., and Yao, X.: Examination of causative link between a spring bloom and dry/wet deposition of Asian dust in the Yellow Sea, China, J. Geophys. Res., 117, D17304, https://doi.org/10.1029/2012JD017983, 2012.

Shi, J. H., Zhang, J., Gao, H. W., Tan, S. C., Yao, X. H., and Ren, J. L.: Concentration, solubility and deposition flux of atmospheric particulate nutrients over the yellow sea, Deep-Sea Res., 97, 43$50,2013$.

Shi, Z., Krom, M. D., Bonneville, S., and Benning, L. G.: Atmospheric processing outside clouds increases soluble iron in mineral dust, Environ. Sci. Technol., 49, 1472-1477, 2015.

Sholkovitz, E. R., Sedwick, P. N., Church, T. M., Baker, A. R., and Powell, C. F.: Fractional solubility of aerosol iron: Synthesis of a global-scale data set, Geochim. Cosmochim. Ac., 89, 173-189, 2012.

Srinivas, B. and Sarin, M. M.: Atmospheric pathways of phosphorous to the Bay of Bengal: contribution from anthropogenic sources and mineral dust, Tellus B, 64, 17174, https://doi.org/10.3402/tellusb.v64i0.17174, 2012.

Srinivas, B. and Sarin, M. M.: Atmospheric deposition of phosphorus to the Northern Indian Ocean, Curr. Sci., 108, 1300-1305, 2015.

Stockdale, A., Krom, M. D., Mortimer, R. J., Benning, L. G., Carslaw, K. S., Herbert, R. J., Shi, Z., Myriokefalitakis, S., Kanakidou, M., and Nenes, A.: Understanding the nature of atmospheric acid processing of mineral dusts in supplying bioavailable phosphorus to the oceans, P. Natl. Acad. Sci. USA, 113, 14639-14644, 2016.

Sun, C., Xie, Z. Q., Kang, H., and Yu, J.: Phosphorus in the aerosols over oceans transported offshore from China to the Arctic Ocean: Speciation, spatial distribution, and potential sources, Adv. Polar. Sci., 26, 232-238, https://doi.org/10.13679/j.advps.2015.3.00232, 2015.

Taylor, S. R.: Abundance of chemical elements in the continental crust: a new table, Geochim. Cosmochim. Ac., 28, 1237-1285, 1964.

Tipping, E., Benham, S., Boyle, J. F., Crow, P., Davies, J., Fischer, U., Guyatt, H., Helliwell, R., Jackson-Blake, L., Lawlor, A. J., Monteith, D. T., Rowe, E. C., and Toberman, H.: Atmospheric deposition of phosphorus to land and freshwater, Environ. Sci., 16, 1608-1617, 2014.
Vicars, W. C., Sickman, J. O., and Ziemann, P. J.: Atmospheric phosphorus deposition at a montane site: Size distribution, effects of wildfire, and ecological implications, Atmos. Environ., 44, 2813-2821, 2010.

Wang, L., Qi, J. H., Shi, J. H., Chen, X. J., and Gao, H. W.: Source apportionment of particulate pollutants in the atmosphere over the Northern Yellow Sea, Atmos. Environ., 70, 425-434, 2013.

Wang, R., Balkanski, Y., Boucher, O., Ciais, P., Penuelas, J., and Tao, S.: Significant contribution of combustion-related emissions to the atmospheric phosphorus budget, Nat. Geosci., 8, 48-54, 2015.

Wei, Q. S., Yao, Q. Z., Wang, B. D., Wang, H. W., and $\mathrm{Yu}, \mathrm{Z}$. G.: Long-term variation of nutrients in the southern Yellow Sea, Cont. Shelf Res., 111, 184-196, https://doi.org/10.1016/j.csr.2015.08.003, 2015.

Weinberger, R., Weiner, T., and Angert, A.: Isotopic signature of atmospheric phosphate emitted from coal combustion, Atmos. Environ., 136, 22-30, 2016.

Yuan, H., Zhang, D., Shi, Y., Li, B., Yang, J., Yu, X., Chen, N., and Kakikawa M.: Cell concentration, viability and culture composition of airborne bacteria during a dust event in Beijing, J. Environ. Sci., 55, 33-40, 2017.

Zamora, L. M., Prospero, J. M., Hansell, D. A., and Trapp, J. M.: Atmospheric P deposition to the subtropical North Atlantic: sources, properties, and relationship to $\mathrm{N}$ deposition, J. Geophys Res., 118, 1546-1562, https://doi.org/10.1002/jgrd.50187, 2013.

Zhang, D., Iwasaka, Y., Shi, G., Zang, J., Hu, M., and Li, C.: Separated status of the natural dust plume and polluted air masses in an asian dust storm event at coastal areas of China, J. Geophys. Res., 110, D06302, https://doi.org/10.1029/2004JD005305, 2005.

Zhang, K. and Gao, H.: The characteristics of Asian-dust storms during 2000-2002: From the source to the sea, Atmos. Environ., 41, 9136-9145, 2007.

Zhang, X.-X., Sharratt, B., Liu, L.-Y., Wang, Z.-F., Pan, X.-L., Lei, J.-Q., Wu, S.-X., Huang, S.-Y., Guo, Y.-H., Li, J., Tang, X., Yang, T., Tian, Y., Chen, X.-S., Hao, J.-Q., Zheng, H.-T., Yang, Y.-Y., and Lyu, Y.-L.: East Asian dust storm in May 2017: observations, modelling, and its influence on the Asia-Pacific region, Atmos. Chem. Phys., 18, 8353-8371, https://doi.org/10.5194/acp18-8353-2018, 2018. 